\title{
Metode Penyelesaian Sengketa Batas Desa Upt Tambak Sari Kecamatan Poto Tano Kabupaten Sumbawa Barat
}

\author{
*Rasyid Ridha, Agus Kurniawan, Febrita Susanti, Sri Apriani Puji Lestari \\ Program Studi Perencanaan Wilayah dan Kota Universitas Muhammadiyah, Mataram, Indonesia \\ rasyidridha673@gmail.com
}

\section{INFO ARTIKEL}

Riwayat Artikel:

Diterima: 24-5-2019

Disetujui: 27-6-2019

Kata Kunci:

Penetapan Batas

Sengketa Batas

Batas Desa Definitif

\section{A. LATAR BELAKANG}

Batas wilayah administrasi Pemerintah Desa menjadi salah satu kepastian penting dalam pengelolaan wilayah beserta sumber dayanya. Pada kenyataannya dari sekitar 80.0oo jumlah desa dan kelurahan, baru sebagian kecil saja yang memiliki batas desa yang telah ditetapkan dan

\begin{abstract}
Abstrak: Desa UPT Tambak Sari merupakan salah satu desa pemekaran di Kecamatan Poto Tano yang memiliki permasalahan terhadap sengketa batas desa dengan desa sekitarnya sehingga menghambat proses penetapan batas desa menjadi definitif, oleh karena itu perlu adanya metode penyelesaian sengketa dalam penetapan batas desa UPT Tambak Sari. Tujuan dari penelitian ini adalah untuk mengetahui proses pelaksanaan penetapan dan penyelesaian sengketa batas Desa UPT Tambak Sari. Metode yang digunakan adalah deskripsi kualitatif melalui pendekatan pemetaan partisipatif serta mengacu pada Peraturan Menteri Dalam Negeri Republik Indonesia Nomor 45 Tahun 2016 Tentang Pedoman Penetapan Dan Penegasan Batas Desa. Hasil yang diperoleh dari penelitian ini yaitu pelaksanaan penetapan batas desa yang dilakukan secara kartometris internal desa, selanjutnya dilakukan musyawarah pemufakatan batas antar desa dengan pemaparan toponimi serta segmen batas desa, namun lemahnya regulasi dan sumber informasi terkait batas desa secara indikatif memicu terjadinya sengketa batas antar desa. dalam proses penetapan batas desa juga telah di sepakati mekanisme penyelasian sengketa batas desa, mekanisme yang di sepakati yaitu adanya laporan terhadap sengketa batas desa kepada tim penyelesaian perbedaan pendapat kemudian dilakukan mediasi dan musyawarah, apabila tidak menemui kesepakatan maka selanjutnya akan di proses secara ajudikasi, dalam proses ini penyelesaian sengketa batas desa UPT Tambah Sari dapat terselesaikan pada tahap mediasi berdasarkan keputusan bersama Bupati Kabupaten Sumbawa Barat dengan menimbang sejarah pembentukan desa serta regulasi yang ada.
\end{abstract}

\begin{abstract}
UPT Tambak Sari is one of the expansion villages in the sub-district of Poto Tano, which has problems against village boundary disputes with surrounding villages, thus inhibiting the process of setting the village boundary to be definitive, therefore it is necessary to Settlement of the village boundary UPT Tambak Sari. The purpose of this research is to know the process of implementing and resolving boundary disputes for UPT Tambak Sari village. The method used is a qualitative description through participatory mapping approaches as well as referring to the Indonesian Ministry of Home Affairs Regulation No. 452016 of village boundaries determination and affirmation guidelines. The results obtained from this research is the implementation of the boundary of village boundaries conducted in the internal Cartometris village, and then carried out the boundary settlement deliberation between villages with the exposure of Toponimi and village boundary segments, but weak Regulations and information sources relating to indicative village boundaries precipitate the boundary disputes between villages. In the village boundary determination process has also been agreed on the mechanisms of dispute the village boundary, the mechanism that agreed is the report of the village boundary dispute to the dispute resolution team was then carried out mediation and Deliberation, if there is no agreement then will be in the process of adjudication, in this process of dispute settlement of the village boundary UPT add Sari can be resolved at the mediation level based on the joint decision of the District regent of Sumbawa The history of village formation and regulation.
\end{abstract}

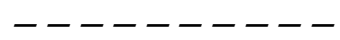


tentang tata cara penetapan dan penegasan batas desa, organisasi pelaksana, proses pengesahan hasil dan penyelesaian sengketa. Penetapan batas desa dilakukan secara kartometrik diatas peta dasar yang telah disepakati, sedangkan penegasan batas mencakup kegiatan peletakan tapal/pilar batas di lapangan berdasarkan hasil penetapan tersebut. Lampiranlampiran Permendagri Nomor 45 Tahun 2016 menjabarkan tentang prinsip-prinsip yang digunakan dan proses penetapan dan penegasan batas desa.

Pembentukan Kabupaten Sumbawa Barat berangkat dari kenyataan bahwa rentang kendali antara pusat kabupaten dengan masyarakat Sumbawa Barat teramat jauh, sehingga mengakibatkan lambannya pelayanan pemerintah kepada masyarakat, lambannya pemerataan pembangunan hingga lambannya upaya peningkatan SDM, Pemekaran wilayah antara Kabupaten Sumbawa Barat dan Kabupaten Sumbawa terjadi pada tahun 2003 dengan dikeluarkanya Undang - Undang Republik Indonesia Nomor 30 Tahun 2003 Tentang Pembentukan Kabupaten Sumbawa Barat di Provinsi Nusa Tenggara Barat, dengan 5 (lima) Kecamatan diantaranya yaitu Kecamatan Seteluk, Kecamatan Brang Rea, Kecamatan Jereweh, Kecamatan Sekongkang dan Kecamatan Taliwang. Sedangkan Kecamatan Poto Tano Sendiri baru Terbentuk di Tahun 2007 dengan dikeluarkannya Peraturan Daerah Nomor 4 Tahun 2007 tentang Pembentukan Kecamatan Poto Tano, yang meliputi wilayah Desa Senayan, Desa Mantar, Desa Persiapan Kiantar, Desa Poto Tano dan Desa UPT Tambak Sari.

Namun keberhasilan pembentukan Kecamatan Poto Tano menyimpan berbagi permasalahan salah satunya mengenai batas administratif di tingkat desa khususnya Desa UPT Tambak Sari yang merupakan Unit Pemukiman Terpadu Transmigrasi dan dialihkan menjadi wilayah Desa yang indikatif sebagaimana yang termuat dalm Peraturan Daerah Kabupaten Sumbawa Barat Nomor 4 Tahun 2007 tentang Pembentukan Kecamatan Poto Tano, akan tetapi Desa UPT Tambak Sari belum memiliki daras hukum tentang pembentukannya, yang artinya Desa UPT Tambak Sari belum memiliki wilayah yang jelas, seringkali pemasalahan ini memicu terjadinya konflik atau sengketa antara segmen batas desa, khusunya segmen desa yang berbatasan dengan Desa UPT Tambak Sari yaitu Desa UPT Tambak Sari dengan Desa Senayan dan Desa UPT Tambak Sari dengan Desa Poto Tano.

Berdasarkan latar belakang di atas, maka adapun rumusan masalah dari kajian penyelesaian sengketa segmen batas desa UPT Tambak Sari adalah sebagai berikut :

1. Bagaimana proses pelaksanaan penetapan batas Desa UPT Tambak Sari?

2. Bagaimana metode penyelesaian sengketa pada segmen batas desa yang berbatasan dengan desa UPT Tambak Sari?
3. Bagaimana terbentuknya batas Desa UPT Tambak Sari yang definitif?

Tujuan dari kajian penyelesaian sengketa segmen batas desa UPT Tambak Sari adalah sebagai berikut :

1. Mengetahui proses pelaksanaan penetapan batas Desa UPT Tambak Sari.

2. Mengetahui metode penyelesaian sengketa pada segmen batas desa yang berbatasan dengan desa UPT Tambak Sari.

3. Mengetahui terbentuknya batas Desa UPT Tambak Sari yang definitif.

\section{B. METODE PENELITIAN}

\section{Jenis Penelitian}

Jenis peneliatian yang digunakan dalam penelitian yaitu penelitian deskriptif yang merupakan suatu bentuk penelitian yang ditujukan untuk mendeskripsikan fenomena-fenomena yang ada, baik fenomena alamiah maupun fenomena buatan manusia. Fenomena tersebut dapat berupa bentuk, aktivitas, karakteristik, perubahan, hubungan, kesamaan, dan perbedaan antara fenomena yang satu dengan fenomena lainnya (Sukmadinata, 2006: 72).

Penelitian ini menggunakan pendekatan secara kualitatif dengan menggunakan wawancara dan observasi sebagai alat pengumpulan data, hasil penelitian disajikan secara deskriptif dengan memaparkan permasalahan dalam penyelesaian sengketa batas Desa UPT Tambak Sari Kecamatan Poto Tano. Pembahasan penelitian dilakukan dengan melihat bagaimana proses penetapan batas desa dan mekanisme penyelesaian sengketa. Untuk mengumpulkan data dilakukan wawancara dengan informan yang paham dengan permasalahan kebijakan penetapan batas desa ini, serta pengumpulan dokumen-dokumen pendukung lainnya.

\section{Analisis Data}

Analisis data yang diperoleh dalam penelitian ini yaitu menggunakan teknik analisis kualitatif, setelah itu dideskripsikan dengan menelaah permasalahan yang ada, manggambarkan, menguraikan, hingga menjelaskan permasalahan-permasalahan yang berkaitan dengan sengketa batas desa. Penggunaan metode deskriptif ini dimaksudkan untuk memperoleh gambaran yang baik, jelas, dan dapat memberikan data sedetail mungkin tentang penyelesaian sengketa batas desa. 
TABEL 1.

Panduan Klasifikasi Perbedaan Pendapat Segmen Batas Desa

\begin{tabular}{|c|c|c|c|c|c|c|}
\hline Kategori & Klasifikasi & $\begin{array}{c}\text { Hubungan } \\
\text { Dengan Para } \\
\text { Pihak Yang } \\
\text { Terlibat }\end{array}$ & $\begin{array}{c}\text { Sejarah } \\
\text { Penyelesaian } \\
\text { Sengketa Atau } \\
\text { Peristiwa Yang } \\
\text { Pernah Terjadi } \\
\end{array}$ & $\begin{array}{c}\text { Ketersediaan } \\
\text { Dokumen Legal }\end{array}$ & $\begin{array}{c}\text { Nilai Di Balik } \\
\text { Segmen Yang } \\
\text { Disengketakan }\end{array}$ & $\begin{array}{c}\text { Usulan } \\
\text { Penyelesaian }\end{array}$ \\
\hline $\mathbf{A}$ & Sulit & $\begin{array}{c}\text { Jarak budaya } \\
\text { dan politik } \\
\text { tinggi serta } \\
\text { melibatkan } \\
\text { pihak yang } \\
\text { 'sulit'. }\end{array}$ & $\begin{array}{l}\text { Pernah dan ada } \\
\text { korban manusia } \\
\text { atau materi. }\end{array}$ & $\begin{array}{c}\text { Ada lebih dari } 1 \\
\text { (satu) dokumen } \\
\text { legal. }\end{array}$ & $\begin{array}{l}\text { Memiliki nilai } \\
\text { ekonomi tinggi, } \\
\text { serta sosial dan } \\
\text { budaya bagi desa } \\
\text { tertentu. }\end{array}$ & Sedikit / tidak ada \\
\hline B & Sedang & $\begin{array}{c}\text { Jarak budaya } \\
\text { dan politik } \\
\text { tidak terlalu } \\
\text { tinggi akan } \\
\text { tetapi } \\
\text { melibatkan } \\
\text { pihak yang } \\
\text { dianggap 'sulit'. }\end{array}$ & $\begin{array}{c}\text { Pernah terjadi } \\
\text { kekerasan namun } \\
\text { tidak } \\
\text { menimbulkan } \\
\text { korban manusia } \\
\text { atau kerugian } \\
\text { materi. }\end{array}$ & $\begin{array}{l}\text { Dokumen legal } \\
\text { tidak terlalu jelas } \\
\text { menunjukkan } \\
\text { batas segemen } \\
\text { atau multi tafsir. }\end{array}$ & $\begin{array}{c}\text { Memiliki nilai } \\
\text { ekonomi yang } \\
\text { berkontribusi pada } \\
\text { salah satu desa saja. }\end{array}$ & $\begin{array}{l}\text { ada tapi hanya } \\
\text { beberapa }\end{array}$ \\
\hline C & Mudah & $\begin{array}{l}\text { Tidak ada jarak } \\
\text { budaya dan } \\
\text { politik. }\end{array}$ & $\begin{array}{l}\text { Tidak ada } \\
\text { kekerasan. }\end{array}$ & $\begin{array}{c}\text { Tersedia dokumen } \\
\text { legal yang diakui } \\
\text { oleh kedua belah } \\
\text { pihak }\end{array}$ & $\begin{array}{l}\text { Memiliki nilai } \\
\text { ekonomi yang dapat } \\
\text { dinegosiasikan. }\end{array}$ & beberapa / banyak \\
\hline
\end{tabular}

Sumber: Participatory Land Use Planning Green Prosperity Project (2017)

Pemetaan parsipatif merupakan pendekatan yang memadukan alat-alat kartografi modern dengan pendekatan partisipatif. Pendekatan ini mampu menggali pengetahuan keruangan (spatial) dari masyarakat setempat karena masyarakat setempat pada dasarnya adalah ahli yang memiliki pengetahuan lingkungan tempat tinggalnya. Peta yang dihasilkan oleh masyarakat setempat menggambarkan tempat mereka tinggal, memperlihatkan tempat-tempat yang oleh masyarakat dianggap penting seperti misalnya batas wilayah adat, pengelolaan sumber daya alam tradisional, daerah sakral, dan sederet tempat penting lainnya.

Pendekatan pemetaan partisipatif juga dimaksudkan untuk (i) meminimalisasi perselisihan batas; (ii) mengakomodasi hak-hak asal-usul; serta (iii) menghargai dan melindungi hak-hak masyarakat adat termasuk kelompok rentan, kelompok marjinal dan kelompok perempuan.

Selain itu analisis data dalam penelian ini juga mengacu pada Peraturan Menteri Dalam Negeri Republik Indonesia Nomor 45 Tahun 2016 Tentang Pedoman Penetapan Dan Penegasan Batas Desa, dalam tata cara pelaksanaan penetapan batas Desa UPT Tambak Sari Kecamatan Poto Tano.

\section{HASIL DAN PEMBAHASAN}

\section{Penetapan Batas Desa}

\section{a) Pengumpulan Data Dan Informas Geosapasial}

Penggalian data secara teknis mengacu pada Perka BIG Nomor 03 Tahun 2016 tentang Batas Desa dan Pemendagri Nomor 45 Tahun 2016 Tengang Pedoman Penetapan Dan Penegasan Batas Desa, selain pada Desa UPT Tambak Sari pengumpulan data juga dilakukan pada desa yang bersebelahan dengan mengumpulakan data primer dan skunder, berikut ini proses pengumpulan data dalam penetapan batas desa.

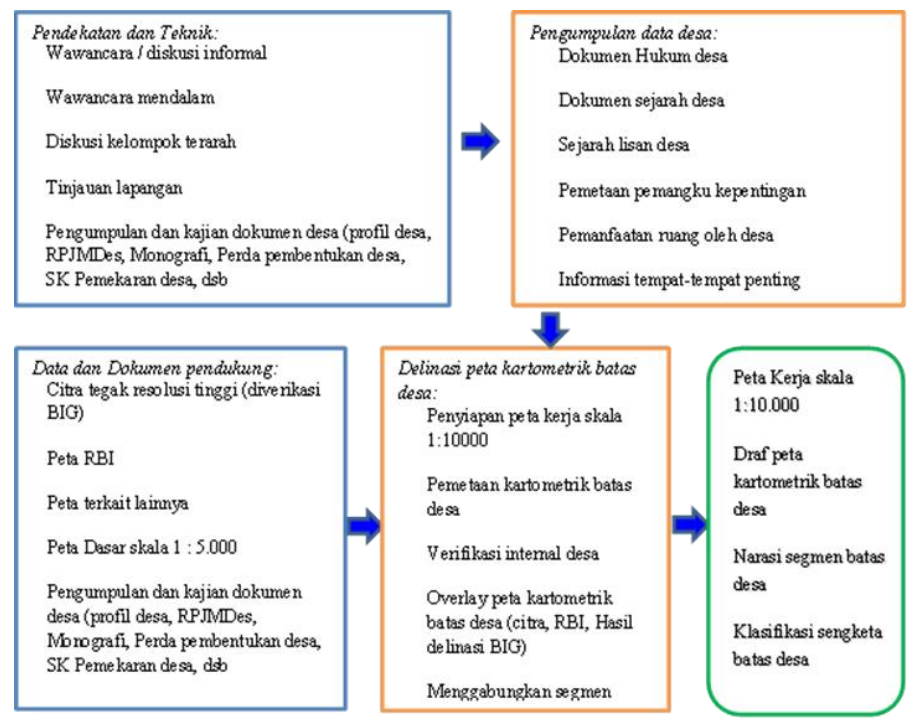

Gambar 1. Bagan Proses Pengumpulan Data Dan Informasi Geosapasial

Kegiatan pemufakatan Batas Desa salah satunya adalah dilakukan identifikasi dan penyepakatan segmen dilakukan di desa dan desa yang bersebelahan dengan desa UPT Tambak Sari. Dalam proses segmen batas desa, Pemerintah Desa menyepakati batas-batas identifikasi desa secara internal dengan melakukan pemberian topinimi batas desa dan penarikan garis secara katomerik

- Pemufakatan Internal Segmen Batas Desa.

Pemufakatan internal desa yang dihadiri oleh Pemerintah Desa dan Tokoh Masyarakat Desa UPT Tambak Sari menyepaki dasar dari batas administrasi 
46 | Jurnal Planoearth | Vol. 4, No. 1, Februari 2019, hal 43-51 wilayah desa yaitu Dokumen RTRW Kabupaten Sumbawa Barat tahun 2010 dan Data BPS tahun 2008 yang menyebutkan luas batas wilayah indikatif Desa UPT Tambak Sari yaitu 1400 Ha. Hali ini disebabkan tumbang tindihnya regulasi pembentukan Desa UPT Tambak Sari. Sedangkan untuk Desa Poto Tano dan Desa Senayan batas indikatif wilayah desa mengacu pada Perda Pembetukan Desa masing - masing yaitu Perda Nomor 7 tahun 2004 Tentang Pembentukan Desa Poto Tano dan Perda Nomor 4 tahun 2001 Tentang Pembentukan Desa Senayan.

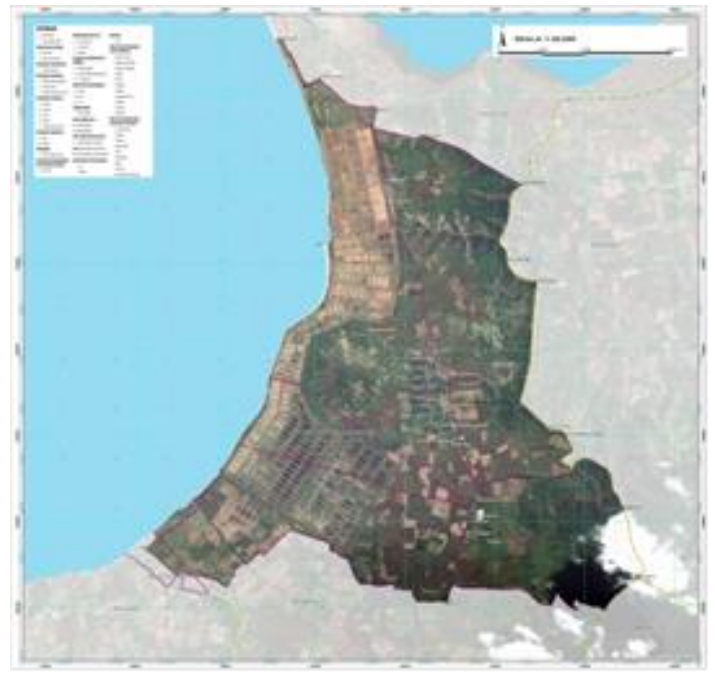

Desa UPT Tambak Sari

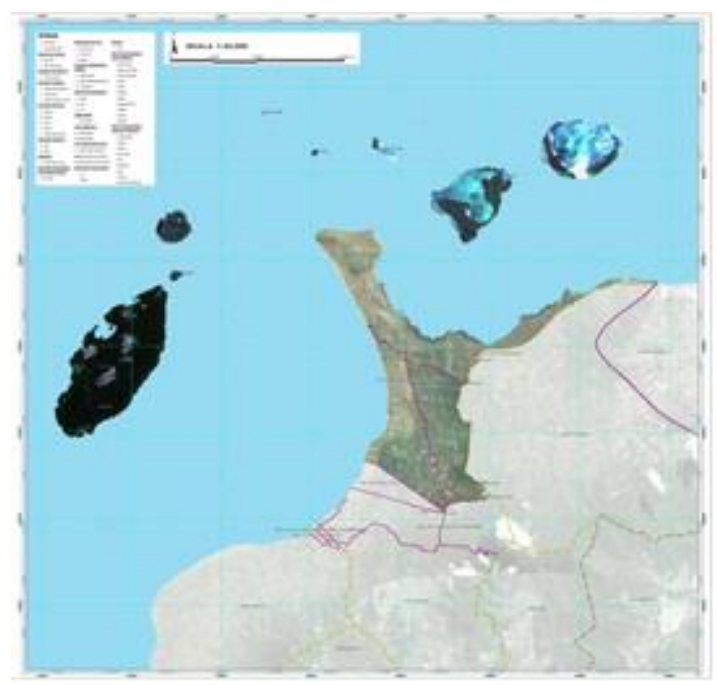

Desa Poto Tano

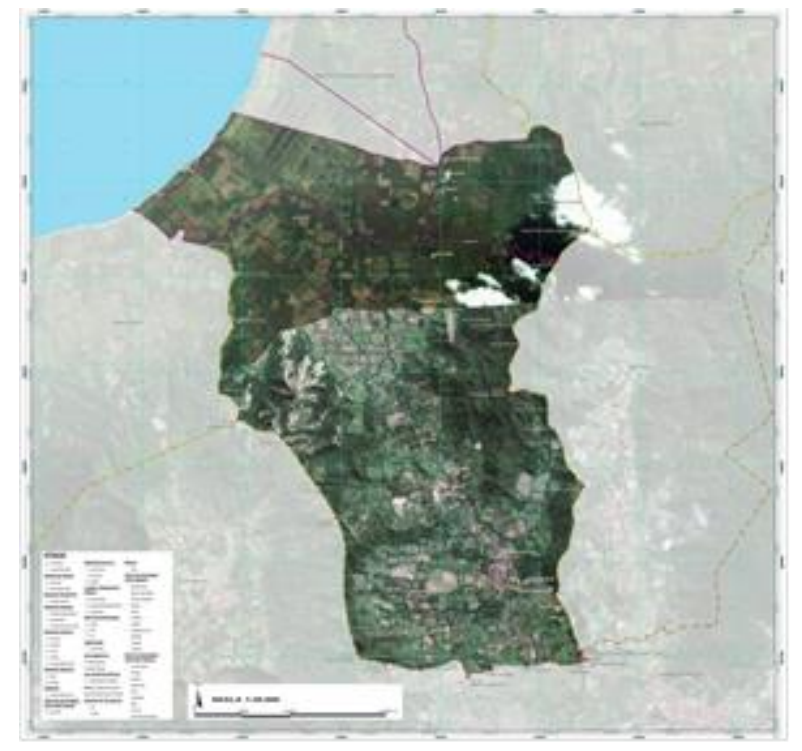

Desa Senayan

Gambar 2. Peta Pemufakatan Internal Batas Desa

- Pemufakatan Antar Segmen Batas Desa

Bedrasarkan pemufakatan internal desa menghasilkan peta batas administrasi menurut versi masing- masing desa disertai toponimi segmen batas desa, hasil pemufakatan internal akan menjadi dasar dalam musyawarah pemufakatan batas desa 
TABEL 2.

Pemufakatan Segmen Batas

\begin{tabular}{cccc}
\hline \multicolumn{1}{c}{ No } & \multicolumn{2}{c}{ Nama Desa } & Perbedaan Segmen \\
\hline \multirow{2}{*}{$\mathbf{1}$} & Poto Tano & Tambak Sari & Pemufakatan segmen batas desa antara Desa Poto Tano dan Desa UPT \\
& & & Tambak Sari belum manghasilkan kesepakatan, dikarenakan kedua Desa \\
& & saling mengklaim lahan tambak udang.
\end{tabular}

Berdasarkan dari sejarah Desa Poto Tano yang disampaikan oleh Kepala Desa Poto Tano menganggap luas wilayah Desa UPT Tambak Sari hanya pada area permukiman, sedangkan pada lahan tambak merupakan bagian dari wilayah administrasi Desa Poto Tano dan Desa Senayan, adapun solusi yang ditawarkan oleh Desa Poto Tano dengan membagi lahan tambak Blok A yang akan menjadi milik Desa Poto Tano sedangkan lahan tambak Blok B, C dan D serta lahan pertanian yang merupakan wilayah perbukitan yang berbatasan dengan Desa Kokarlian menjadi wilayah Desa UTP Tambak Sari. Akan tetapi usulan tersebut tidak disetujui oleh Desa Tambak Sari yang di wakili oleh Kepala Desa UTP Tambak Sari, karena lahan tambak merupakan identitas Desa UPT Tambak Sari dan tetap mengacu pada luasan wilayah seluas $1400 \mathrm{Ha}$ (Sumber BPS 2008) dan SK Badan Pertanahan Nasional Nomor 50 Tahun 2000 tentang Pemberian Pengelolaan Hak Atas Nama Badan Administrasi Kependudukan dan Mobilisasi Penduduk Atas Tanah di Kabupaten Sumbawa Barat dengan luas kawasan tambak dan permukiman 299 Ha.

2 Tambak Sari Senayan Tidak beda jauh dengan hasil pemufakatan sebelumnya antara Desa Poto Tano dan UPT Tambak Sari yang belum menghasilkan kesepakatan, pada pemufakatan segmen batas desa antara Desa Tambak sari dan Desa Senayan, menghasilkan berita acara yang sama yaitu bersepakat untuk belum bersepakat.

Perbedaan pendapat kedua desa berawal dari ketidak sesuaian luas wilayah Desa Tambak Sari menurut Desa Senayan dengan kondisi dilapangan, penarikan garis batas desa dalam pemufakatan internal Desa Tambak Sari Mengklaim luas wilayahnya mencapai 1400 Ha (Sumber BPS 2008) hal ini berdampak terhadap penarikan garis batas desa bagian selatan berbatasan dengan Desa Kiantar yang di tengah kedua desa tersebut masih ada wilayah Desa senayan termasuk salah satu Dusun milik Desa Senayan yaitu Desun Spakek. Permasalahan lain, Desa Senayan sendiri menklaim wilayah desanya hingga wilayah Desa Tambak Sari termasuk didalamnya Blok C dan Blok D.

Sumber: Hasil Musyawah Pemufakatan Batas Desa (2017).

Berdasarkan hasil pemufakatan antar segmen batas desa, dimana segmen batas desa antara Desa Poto Tano dan Desa UPT Tambak Sari serta segmen batas Desa Senyan dan Desa UPT tambak Sari belum menemui kesepakatan dan tertuang dalam berita acara ketidak sepakatan. Dari pemufakatan juga menghasilkan fakta - fakta baru terkait regulasi yang menjadi acuan bagi Desa UPT Tambak Sari, yaitu Perda Nomor 6 tahun 2015 tengang Pembetukan Desa UPT Tambak Sari dan SK Badan Pertanahan Nasional Nomor 50 Tahun 2000 yang menjadi dasar oleh Pemerintah Daerah mengubah status permukiman transmigrasi menjadi Desa UPT Tambak Sari.

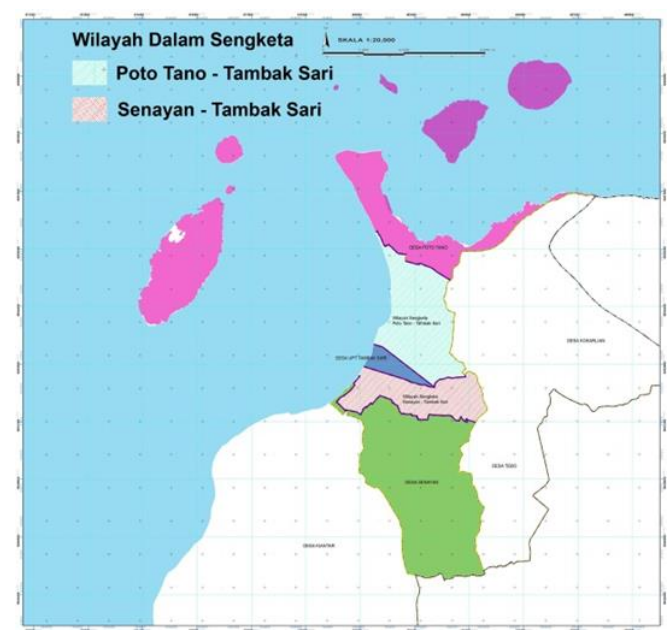

Gambar 3. Peta Pemufakatan Internal Batas Desa 


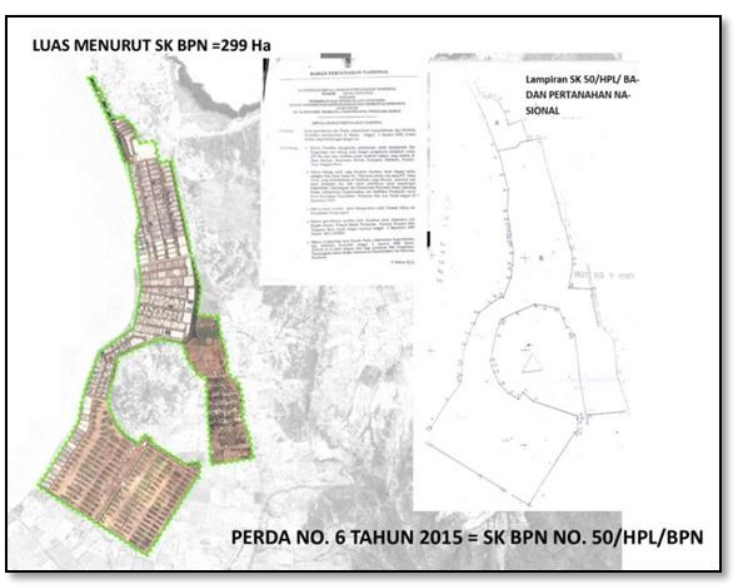

Gambar 4. Penelusuran Sketsa dan Koordinat desa UPT Tambak Sari Berdasarkan Perda Perda Nomor 6 tahun 2015 Dan SK BPN Nomor 50 Tahun 2000. segmen batas desa dengan desa yang bersebelahan. Pembandingan informasi antar desa dengan data yang sudah diperoleh kemudian dianalisis sederhana secara deskriptif kualitatif mengacu pada panduan klasifikasi perbedaan pendapat segmen batas desa untuk menentukan klasifikasi yang dimulai dari yang sudah sama pemahaman, ada sedikit perbedaan, dan ada perbedaan mencolok atau saling klaim wilayah yang didasari kepentingan dengan alasan kuat. Adapun kalisifikasi perbedaan pendapat berdasarkan penggalian data yang disajikan dalam Tabel 3 .

\section{Penyelesaian Sengketa Batas Desa}

a) Penggalian data Sengketa segmen batas desa.

Berdasarkan hasil penarikan garis indikatif segmen batas desa, kemudian dilakukan overlay peta batas desa untuk mengetahui kesamaan dan perbedaan garis

TABEL 3.

Klasifikasi Perbedaan Pendapat Segmen Batas Desa

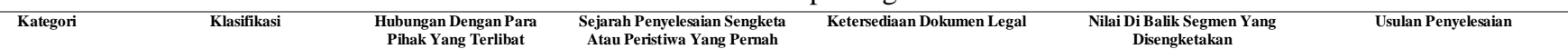
Terjadi

\begin{tabular}{|c|c|c|c|c|c|c|}
\hline \multicolumn{7}{|c|}{ Segmen Batas Desa Poto Tano dan Desa UPT Tambak Sari } \\
\hline B & Sedang & $\begin{array}{l}\text { Memiliki perbedaan budaya } \\
\text { dan tingginya isue politik }\end{array}$ & $\begin{array}{c}\text { Pernah terjadi kekerasan namun } \\
\text { tidak menimbulkan korban } \\
\text { manusia atau kerugian materi } \\
\text { dalam dalam permasalahan } \\
\text { perebutan lahan tambak }\end{array}$ & $\begin{array}{l}\text { Dokumen legal tidak terlalu jelas } \\
\text { menunjukkan batas segemen atau } \\
\text { multi tafsir. }\end{array}$ & Memiliki nilai ekonomi & $\begin{array}{l}\text { Penukaran wilayah antara } \\
\text { lahan tambak yang dimiliki } \\
\text { Desa UPT Tambak Sari } \\
\text { dengan lahan pertanian milik } \\
\text { Desa Poto Tano }\end{array}$ \\
\hline
\end{tabular}

\begin{tabular}{|c|c|c|c|c|c|c|}
\hline \multicolumn{7}{|c|}{ Segmen Batas Desa Poto Tano dan Desa UPT Tambak Sari } \\
\hline B & Sedang & $\begin{array}{l}\text { Memiliki perbedaan } \\
\text { budaya. }\end{array}$ & $\begin{array}{l}\text { Pernah terjadi kekerasan namun } \\
\text { tidak menimbulkan korban } \\
\text { manusia atau kerugian materi } \\
\text { dalam dalam permasalahan } \\
\text { perebutan lahan pertanian yang } \\
\text { termasuk dalam lahan HGU }\end{array}$ & $\begin{array}{l}\text { Dokumen legal tidak terlalu jelas } \\
\text { menunjukkan batas segemen atau } \\
\text { multi tafsir. }\end{array}$ & $\begin{array}{l}\text { Memiliki nilai ekonomi yang } \\
\text { berkontribusi pada salah satu desa } \\
\text { saja. }\end{array}$ & $\begin{array}{c}\text { Kejelasan secara pengelolaan } \\
\text { lahan HGU dan cakupan luas } \\
\text { lahan HGU yang mempengaruhi } \\
\text { batas desa }\end{array}$ \\
\hline
\end{tabular}

Sumber: Hasil Musyawah Pemufakatan Batas Desa dan Panduan Klasifikasi Perbedaan Pendapat Segmen Batas Desa (2017).

Secara klasifikasi perbedaan pendapat batas desa pada kedua segmen diperoleh hasil klasifikasi B dengan kategori sedang, selain dari kelima faktor klasifikasi juga didukung dengan indetifikasi hasil musyawarah pemufakatan batas desa, yaitu:

1) Segmen Batas Desa Poto Tano dan Desa UPT Tambak Sari

- Segmen antar batas Desa Poto Tano dan Desa Tambak Sari mengalami tumpang tindih atau overlapping titik atau toponimi batas desa dan garis batas kedua desa yang di gambakan secara katometrik.

- Lemahnya regulasi atau dasar hukum pembentukan Desa UPT Tambak Sari memicu perbedaan pendapat dengan Desa Poto Tano.

- Sebagai desa pemekaran dari desa induk Desa Senayan, Desa Poto Tano hanya mengakui batas wilayah Selatan hanya dengan Desa Senayan.
- Luas Desa Poto Tano semakin kecil seiring terjadinya pemekaran desa yaitu dengan terbentuknya Desa Kokarlian dan Desa UPT Tambak Sari yang dimana kedua desa tersebut dulunya merupakan bagian dari Desa Poto Tano.

- Ketidak jelasan pengurusan administrasi oleh masyarakat kepada pemerintah desa dampak dari belum adanya batas administrasi yang definitif.

2) Segmen Batas Desa Senayan dan Desa UPT Tambak Sari

- Segmen antar batas kedua desa mengalami tumpang tindih dimana pada saat pemufakatan internal kedua desa sudah terlihat overlapping titik atau toponimi batas desa dan garis batas desa.

- Lemahnya regulasi atau dasar hukum pembentukan Desa Tambak Sari memicu perbedaan pendapat dengan Desa Senayan. 
- Sebagai desa induk Desa Senayan memiliki sejarah terkait lahan yang di tempati penduduk tranmigrasi di Desa UPT Tambak Sari.

- Pada saat pemufakatan internal Desa Tambak Sari mengklaim luas wilayahnya mencapai $1400 \mathrm{Ha}$ (Sumber BPS 2008).

- Keluarnya PERDA Nomor. o6 Tahun 2015 tentang Pembentukan Desa UPT. Tambak Sari. PERDA ini menindaklanjuti dari PERDA Nomor 04 Tahun 2007 tentang Pembentukan Kecamatan Poto Tano.

- Perebutan atau saling klaim lahan Hak Guna Usaha (HGU) yang sebagai mana tercantum dalam SK Badan Pertanahan Nasional Nomor 50 Tahun 2000 yang menjadi dasar oleh Pemerintah Daerah mengubah status permukiman transmigrasi menjadi Desa UPT Tambak Sari. terutama pada kawasan tambak udang yang dalam hal ini di kelola oleh perusahaan swasta juga terjadi di antara segmen batas desa Poto Tano dengan Desa Tambak Sari.

b) Pembentukan Mekanisme Penyelesaian Sengketa Batas Desa

Dalam rangka penyelesaian sengketa batas desa perlu dilakukan klasifikasi perbedaan pendapat/sengketa dan penyepakatan batas desa, maka hal pertama dilakukan adalah pembentukan tim penyelesaian sengketa batas desa dengan beberepa kriteria yang menjadi kesepatan oleh masyrakat yaitu bersikap adil, memiliki pemaham terhadap tata ruang dan tata laksana pemerintahan desa yang termasuk tata aturan dan perundang-undangan yang ada di tingkat desa serta bangian dari tokoh masyarakat.

Adapun mekanisme yang di kesepakati dalam memyelesaikan sengketa batas desa yaitu:

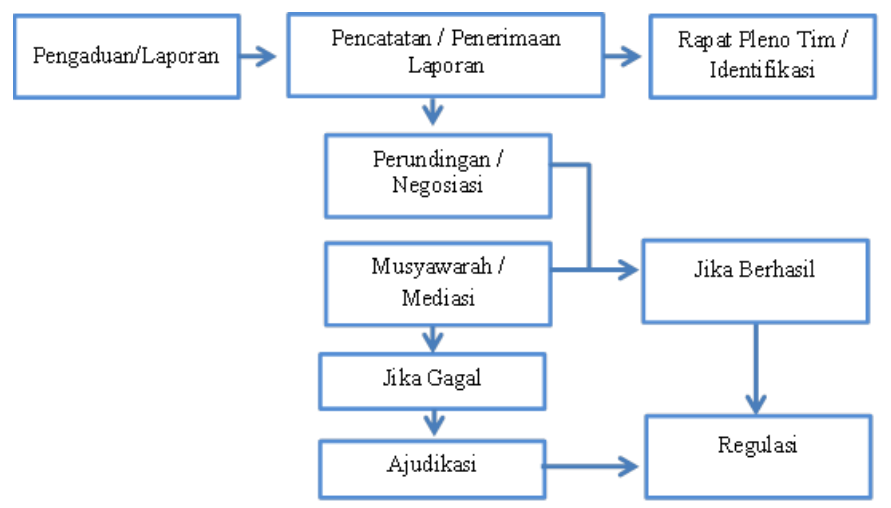

Gambar 5. Bagan Mekanisme Penyelesaian Perbedaan Pendapat Batas Desa

\section{Tahap Pengaduan / Laporan :}

proses pengaduan atau laporan bertujuan untuk menginformasikan hasil dari pemufakatan batas desa dengan adanya pengaduan yang menjadi pemberitahuan disertai permintaan oleh desa yang bersengketa kepada tim penyelesaian sengketa batas desa yang berwenang untuk menindak lanjuti sesuai mekanisme yang di sepakati.

\section{Tahap Penerimaan Pengaduan :}

Berdasarkan pengaduan atau laporan dari hasil pemufakatan segmen batas desa yang tidak menemui kesepakatan, maka tim penyelesaian sengkat batas desa akan memerima pengaduan atau laporan disertai pengumpulan data yang telah diklasifikasikan yang akan menjadi sumber informasi dalam pengambilan keputusan

\section{Tahap Identifikasi :}

Kegiatan ini bertujan untuk mengumpulkan serta meneliti hingga mencatat data dan informasi, agar dikesesuaikan dengan kelengkapan data dalam penyelesaian batas desa.

Beberapa data dan informasi yang di peroleh dari masing-masing desa yaitu, berita acara ketidak sepakat segmen batas desa, peta batas desa indikaf berdasarkan pemufakatan internal desa, kalisifikasi sengketa batas desa dan kelengkapan dokumen desa.

\section{Tahap Perundingan:}

Kegiatan perundingan dilakukan dengan cara musyarawarah. Perundingan merupakan tindakan atau proses penawaran solusi usulan penyelesaian sengketa untuk meraih kesepakatan yang bisa diterima oleh desa yang bersengketa.

Pada tahap perundingan ini kedua segmen batas desa belum menemui kesepakatan karena solusi yang diusulkan dianggap tidak memihak pada desa yang lain.

\section{Tahap Musyawarah / Mediasi:}

Tahap Mediasi dalam penyelesaian sengketa dilakukan dengan sistem penyelesaian sengketa melalui sistem perundingan atau mufakat beberapa pihak dengan dibantu oleh mediator yg tidak punyai kewenangan memutus atau memaksakan satu buah penyelesaian. Dalam proses mediasi ini bupati Kabupaten Sumbawa Barat di tunjuk sebagai mediator dengan konsep utama sistem mediasi yaitu perundingan yang esensinya sama seperti sistem musyawarah. Proses mediasi juga di hadirkan tim penyelesaian sengketa batas desa, pemerintah desa dan tokoh masyarakat dari desa yang bersengketa.

Berdasarkan hasil mediasi segmen batas desa yang berseketa menemui hasil kesepakatan dengan hasil kesepakatan dimuat dalam berita acara kesepakatan batas desa dan Peraturan Bupati tentang Peta Batas Desa.

\section{Tahap Ajudikasi:}


Proses ajudikasi dalam penyelesaian sengketa merupakan salah satu cara penyelesaian konflik atau sengketa melalui pihak ketiga yang mana pihak ketiga ini ditunjuk oleh pihak yang bersengketa untuk menetapkan suatu keputusan yang bersifat mengikat. Dalam hal ini pihak ketiga tersebut adalah lembaga peradilan. Hakim akan memutuskan peradilan di pengadilan sesuai peraturan perundang-undangan yang berlaku.

Berdasarkan pengaplikasian mekamanise penyelesaian sengkata batas desa, segmen batas yang sebelumnya tidak bersepakat, melalui proses mediasi menghasilkan kesepakatan yang termuat dalam Peratuaran Bupati tetang Peta Batas Desa, penarikan garis batas desa di dasari oleh topinimi batas desa dengan segmen batas alam dan buatan sebagai mana yang diamanatkan oleh Peraturan Menteri Dalam Negeri Nomor 45 Tahun 2016 tentang Pedoman Penetapan dan Penegasan Batas Desa, batas desa hasil mediasi segmen batas desa dapat dilihat pada gambar 6.

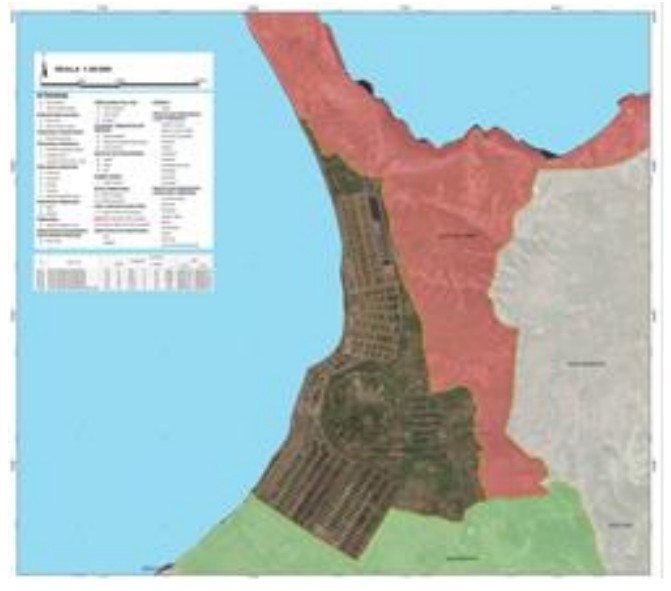

Desa UFT Tambak Sari

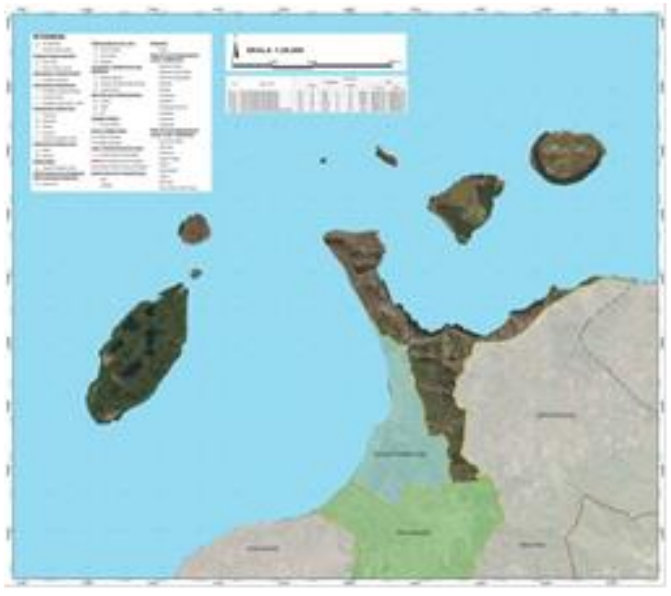

Desa Poto Tano

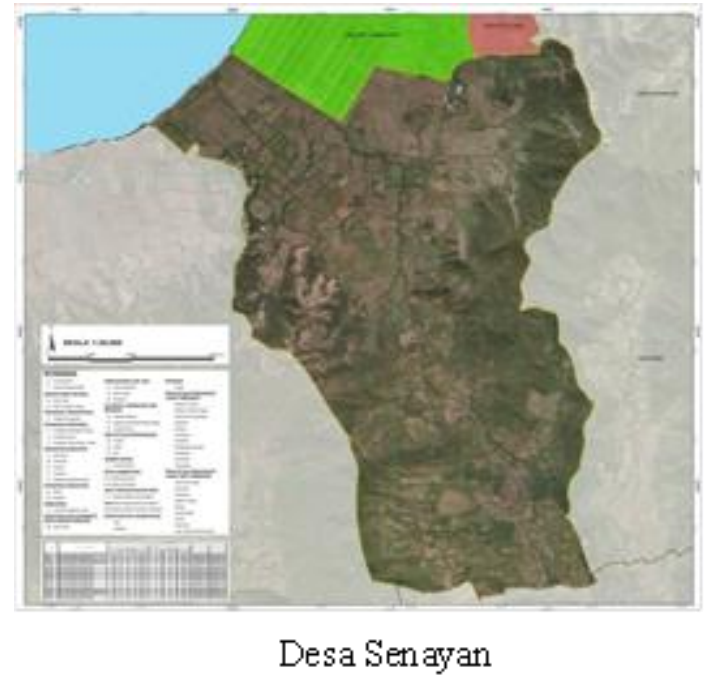

Gambar 6. Peta Batas Desa Definitif

\section{SIMPULAN DAN SARAN}

Berdasarkan hasil penelitian yang telah dibahas, maka kesimpulan yang dapat diambil dari penelitian ini adalah sebagai berikut:

1. Proses penetapan batas desa dilakukan dengan pengumpulan data dan informasi geospasial dan dilakukan pemufakatan segmen batas desa, berdasarkan hasil pemufakatan batas desa, dua segmen batas desa antara Desa Poto Tano dengan Desa UPT Tambak Sari serta Segmen Batas Desa Senaya dengan Desa UPT Tambak sari dalam pemufakatan belum menemui kesepakatan dikarenakan belum jelasnya regulasi yang menjadi dasar pernarikan garis batas desa secara katomerik yang mengakibatkan terjadinya overlepping pada garis batas desa.

2. Menyikapi terjadinya sengketa batas desa, maka dibentuk tim dan mekanisme atau metode penyelesaian sengketa batas desa yang di sepakati oleh desa yang bersengketa, dalam mekanisme ini desa yang bersengketa dapat mengadukan kasus melalui pelaporan yang menjadi bahan dalam identifikasi permasalah terjadinya sengketa kemudian dilanjutkan pada proses perundingan dan mediasi dengan mediator yang termuat dalam berita acara sebagai mana yang telah disepakati oleh desa yang bersengketa.

3. Dalam proses mediasi segmen batas desa dapat di sepakati oleh desa - dasa yang bersengketa, sebagai implementasi dari kesepatan maka segmen batas desa yang disepakti termuat dalam Peraturan Bupati tengtang Peta Batas Desa yang definitif, yaitu Peta Batas Desa Poto Tano, Peta Batas Desa UPT Tambak Sari dan Peta Batas Desa Senayan.

Beberapa pemikiran ataupun saran yang dapat menjadi arahan terkait dengan permasalahan yang ada dalam penelitian ini sebagai berikut. 
1. Sebagai upaya pencegahan terjadinya sengketa batas desa khususnya pada desa persiapan, maka sudah sepatutnya PERDA Pembentukan Desa menghasilkan Peta Batas Desa yang Definitif sesuai dengan Peraturan Menteri Dalam Negeri Nomor 45 Tahun 2016 tentang Pedoman Penetapan dan Penegasan Batas Desa.

2. Dalam mengatasi terjadinya sengketa batas desa yang sama dikarenakan lemahnya regulasi diharapkan Peratuaran Bupati Kabupaten Sumbawa Barat tentang Tentang Peta Batas Desa dapat ditindaklajuti sebagai dasar revisi PERDA pembentukan Desa UPT Tambak Sari, Desa Poto Tano dan Desa Senayan.

3.Minimnya ketersediaan sumberdaya manusia (SDM) dan sumberdaya peralatan pengelolaan data spasial di tingkat desa untuk penataan batas wilayah desa kiranya perlu menjadi perhatian semua pihak.

\section{DAFTAR RUJUKAN}

[1] MCA-Indonesia, 2017. Panduan Teknis Penetapan dan Penegasan Batas Desa, Jakarta.

[2] Peraturan Daerah Kabupaten Sumbawa Barat Nomor 4 Tahun 2007 tentang Pembentukan Kecamatan Poto Tano, Taliwang

[3] Peraturan Daerah Kabupaten Sumbawa Barat Nomor 6 Tahun 2015, tentang Pembentukan Desa UPT. Tambak Sari, Taliwang

[4] Peraturan Kepala Badan Informasi Geospasial. Nomor 3 Tahun 2016. Tentang Spesifikasi Teknis Penyajian Peta Desa, Cibinong.

[5] Peraturan Menteri Dalam Negeri Republik Indonesia Nomor 45 Tahun 2016 Tentang Pedoman Penetapan Dan Penegasan Batas Desa, Jakarta.

[6] Surat Keputusan Badan Pertanahan Nasional, Nomor 50 Tahun 2000, tentang Pemberian Pengelolaan Hak Atas Nama Badan Administrasi Kependudukan dan Mobilisasi Penduduk Atas Tanah di Kabupaten Sumbawa Barat, Jakarta. 